CrossMark

\&lick for updates

Cite this: Dalton Trans., 2016, 45, 15481

\title{
Synthesis and structures of a pincer-type rhodium(III) complex: reactivity toward biomolecules $\uparrow$
}

\author{
Milan M. Milutinović, ${ }^{\text {ad }}$ Jovana V. Bogojeski, ${ }^{\star a}$ Olivera Klisurić, ${ }^{b}$ Andreas Scheurer, ${ }^{c}$ \\ Sofi K. C. Elmroth ${ }^{d}$ and Živadin D. Bugarčić ${ }^{\star a}$
}

\begin{abstract}
A novel rhodium(III) complex [Rh"' $\left.\left(\mathrm{H}_{2} \mathrm{~L}^{\mathrm{BBu}}\right) \mathrm{Cl}_{3}\right](\mathbf{1})\left(\mathrm{H}_{2} \mathrm{~L}^{\mathrm{tBu}}=2,6\right.$-bis(5-tert-butyl-1H-pyrazol-3-yl)pyridine) containing a pincer type, tridentate nitrogen-donor chelate system was synthesized. Single crystal X-ray structure analysis revealed that 1 crystallizes in the orthorhombic space group Pbcn with $a=20.7982(6)$, $b=10.8952(4), c=10.9832(4) \AA, V=2488.80(15) \AA^{3}$, and eight molecules in the unit cell. The rhodium center in the complex $\left[\mathrm{Rh}^{\mathrm{II}}\left(\mathrm{H}_{2} \mathrm{~L}^{\mathrm{tBu}}\right) \mathrm{Cl}_{3}\right](\mathbf{1})$ is coordinated in a slightly distorted octahedral geometry by the tridentate $\mathrm{N}, \mathrm{N}, \mathrm{N}$-donor and three chloro ligands, adopting a mer arrangement with an essentially planar ligand skeleton. Due to the tridentate coordination of the $\mathrm{N}, \mathrm{N}, \mathrm{N}-$ donor, the central nitrogen atom $\mathrm{N} 1$ is located closer to the $\mathrm{Rh}^{\prime \prime \prime}$ center. The reactivity of the synthesized complex toward small biomolecules (L-methionine (L-Met), guanosine-5'-monophosphate (5'-GMP), L-histidine (L-His) and glutathione (GSH)) and to a series of duplex DNAs and RNA was investigated. The order of reactivity of the studied small biomolecules is: 5'-GMP > GSH > L-Met > L-His. Duplex RNA reacts faster with the $\left[\mathrm{Rh}^{\prime \prime \prime}\left(\mathrm{H}_{2} \mathrm{~L}^{\mathrm{BB}}\right) \mathrm{Cl}_{3}\right]$ complex than duplex DNA, while shorter duplex DNA (15mer GG) reacts faster compared with 22mer GG duplex DNA. In addition, a higher reactivity is achieved with a DNA duplex with a centrally located GG-sequence than with a 22GTG duplex DNA, in which the GG-sequence is separated by a T base. Furthermore, the interaction of this metal complex 1 with calf thymus DNA (CT-DNA) and bovine serum albumin (BSA) was examined by absorption (UV-Vis) and emission spectral studies (EthBr displacement studies). Overall, the studied complex exhibited good DNA and BSA interaction ability.
\end{abstract}

Received 13th July 2016, Accepted 26th August 2016

DOI: $10.1039 / c 6 d t 02772 \mathrm{e}$

www.rsc.org/dalton carboplatin and oxaliplatin, are currently in global clinical use. This fact has led to growing interest in the properties of complexes containing metals other than platinum. ${ }^{1-3}$ Over two decades ruthenium metallo-drugs were intensively investigated, revealing these types of drugs to exhibit better properties compared to platinum metallo-drugs, but to date none of these metallo-drugs have been approved for clinical use. ${ }^{1-3}$ Presently, research in this field is more directed toward metal complexes from the $9^{\text {th }}$ group of the Periodic Table, for example iridium and rhodium. ${ }^{4-6}$

The antitumor activity of the rhodium(III) salt $\mathrm{RhCl}_{3} \cdot x \mathrm{H}_{2} \mathrm{O}$, was first mentioned in 1953, more than a decade before the antitumor activity of a platinum complex was reported. ${ }^{7,8}$ The main drawback of the metal complexes from the $9^{\text {th }}$ group of the Periodic Table is that they have shown inertness and only recently $\mathrm{Rh}^{\mathrm{III}}$ complexes have received increasing attention. Their reactivities, binding preferences, and cellular uptake are strongly dependent on their ligand combination and coordination geometry. ${ }^{4}$ Also, this specific characteristic of the complexes of $9^{\text {th }}$ group metals, inertness, has contributed to the design of complexes which can target specific proteins and enzyme inhibitors as well as DNA. ${ }^{4}$ To date, a lot of $\mathrm{Rh}^{\mathrm{III}}$ complexes such as half-sandwich $\mathrm{Rh}^{\mathrm{III}}$ complexes and 
<smiles></smiles><smiles>CSCCC(N)C(=O)O</smiles>

L-Methionine (L-Met)<smiles>NC(Cc1c[nH]cn1)C(=O)O</smiles>

L-Histidine (L-His)<smiles>Nc1nc2c(ncn2[C@H](O)O[C@H](O)COP(=O)([O-])[O-])c(=O)[nH]1</smiles>

guanosine-5'-monophosphate (5'-GMP)

Fig. 1 Structures of the investigated rhodium(III) complex 1 and nucleophiles, along with their abbreviations.

polypyridyl $\mathrm{Rh}^{\mathrm{III}}$ complexes were investigated. ${ }^{4}$ However, our interest was directed towards the pincer-type ligands since these ligands were investigated during the past few decades due to their very specific characteristics (e.g. photophysical and biological properties) and diverse applications in catalysis. ${ }^{9,10}$ Therefore, the aim of our research was to see if this type of ligand can enhance the reactivity of $\mathrm{Rh}^{\mathrm{III}}$ complexes toward biomolecules which are characteristic binding targets for cisplatin.

Based on these facts, the focus of this paper was the design of a new $\mathrm{Rh}^{\mathrm{III}}$ complex with increased activity by the use of a spectator ligand to notably improve the rate of substitution. Also, the studies of the substitution process have been performed with selected biomolecules (Fig. 1), a duplex of DNA and RNA, CT-DNA as well as protein albumin in order to improve the understanding of biological reactivity preferences. These kinds of biomolecules were chosen since these biomolecules are known as targeting molecules for $\mathrm{Pt}^{\mathrm{II}}$ complexes, thus, enabling a comparison of the properties of the new $\mathrm{Rh}^{\text {III }}$ complex with $\mathrm{Pt}^{\mathrm{II}}$ complexes, which have established antitumor features.

\section{Results and discussion}

\section{Preparation and structure of $\left[\mathrm{Rh}^{\mathrm{III}}\left(\mathrm{H}_{2} \mathrm{~L}^{t \mathrm{Bu}}\right) \mathrm{Cl}_{3}\right](1)$}

The complex $\left[\mathrm{Rh}^{\mathrm{III}}\left(\mathrm{H}_{2} \mathrm{~L}^{t \mathrm{Bu}}\right) \mathrm{Cl}_{3}\right]$ (1) (Fig. 1) was synthesized by stirring equimolar amounts of $\mathrm{RhCl}_{3} \cdot x \mathrm{H}_{2} \mathrm{O}$ and 2,6-bis(5-tertbutyl-1H-pyrazol-3-yl)pyridine $\left(\mathrm{H}_{2} \mathrm{~L}^{t \mathrm{Bu}}\right)$ in ethanol at $50{ }^{\circ} \mathrm{C}$. The
$\mathrm{Rh}^{\mathrm{III}}$ complex 1 was characterized by means of standard analytical methods and its purity was confirmed by elemental analysis. Single crystals suitable for X-ray structure analysis were also obtained for the determination of the molecular structure.

\section{Crystal structure discussion}

The perspective view of the molecular structure of the $\mathrm{Rh}^{\mathrm{III}}$ complex 1 is shown in Fig. 2. Selected metal-ligand bond lengths and angles of $\mathbf{1}$ are given in Table 1.

Suitable crystals for X-ray structural analysis were obtained from a DMF/water mixture of $\mathbf{1}$ upon prolonged standing. The complex $\left[\mathrm{Rh}^{\mathrm{III}}\left(\mathrm{H}_{2} \mathrm{~L}^{t \mathrm{Bu}}\right) \mathrm{Cl}_{3}\right] \cdot 2 \mathrm{H}_{2} \mathrm{O}\left(\mathbf{1} \cdot 2 \mathrm{H}_{2} \mathrm{O}\right)$ crystallizes in the orthorhombic crystal system and the $P b c n$ space group, with one half of the molecule in the asymmetric unit since the 2-fold axis passes through the special position of Rh1, Cl1, N1, and $\mathrm{C} 10$ atoms. In the outer sphere of the complex, there are two $\mathrm{H}_{2} \mathrm{O}$ solvent molecules. From a structural point of view, one must emphasize two features of complex 1, namely, the coordination of the Rh1 atom and the crystal packing. The rhodium center in complex $\mathbf{1}$ is coordinated in a slightly distorted octahedral geometry with the tridentate $\mathrm{N}, \mathrm{N}, \mathrm{N}-$ donor adopting a mer arrangement with the essentially planar ligand skeleton (Fig. 2). Due to the tridentate coordination of the $\mathrm{N}, \mathrm{N}, \mathrm{N}$-donor, the central nitrogen atom $\mathrm{N} 1$ is located closer to the rhodium(III) center (Table 1). It therefore applies a trans influence to $\mathrm{Cl} 1$, which explains the slightly larger value of the Rh1-Cl1 bond length compared to Rh1-Cl2 (Table 1). The 


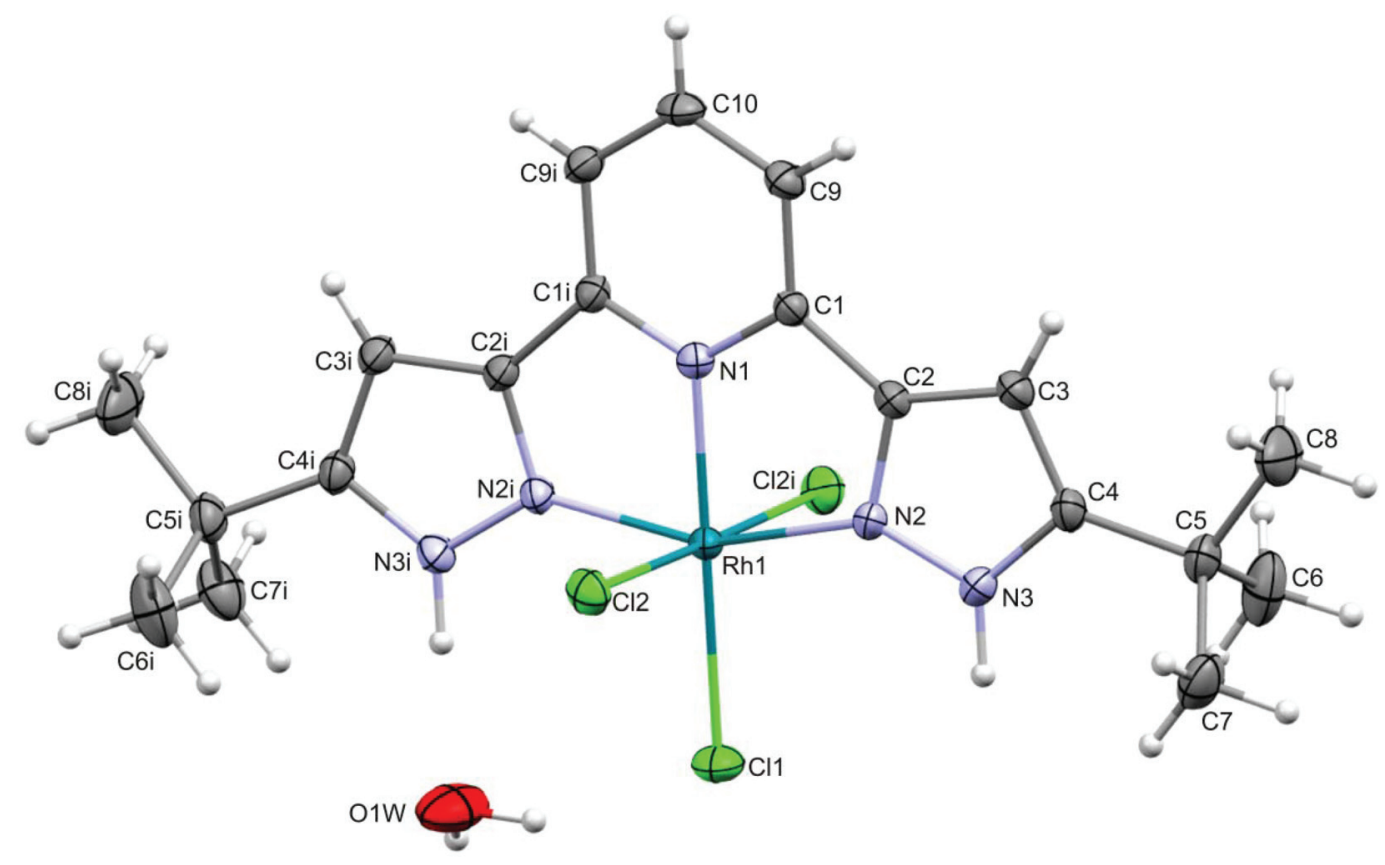

Fig. 2 ORTEP presentation of the molecular structure of the $\left[\mathrm{Rh}^{\mathrm{III}}\left(\mathrm{H}_{2} \mathrm{~L}^{\mathrm{tBu}}\right) \mathrm{Cl}_{3}\right]$ complex together with one of the cocrystallized water molecules and the non- $\mathrm{H}$ atom numbering scheme with thermal ellipsoids at the $30 \%$ probability level. Symmetry transformations used to generate equivalent atoms labeled with $\mathrm{i}$ is: $-x+1, y,-z+3 / 2$.

Table 1 Selected geometrical parameters for complex $\left[\mathrm{Rh}^{\prime \prime \prime}\left(\mathrm{H}_{2} \mathrm{~L}^{\mathrm{tBu}}\right) \mathrm{Cl}_{3}\right]$ (1)

Bond lengths $[\AA]$

\begin{tabular}{ll}
\hline Rh1-N1 & $1.968(3)$ \\
Rh1-N2 & $2.034(2)$ \\
Rh1-Cl1 & $2.3690(10)$ \\
Rh1-Cl2 & $2.3276(7)$ \\
N2-N3 & $1.346(3)$ \\
N1-C1 & $1.346(3)$ \\
N2-C2 & $1.346(3)$ \\
N3-C4 & $1.354(3)$ \\
\hline
\end{tabular}

Bond angles [ $\left.{ }^{\circ}\right]$

N1-Rh1-N2

$\mathrm{N} 2{ }^{\mathrm{i}}-\mathrm{Rh} 1-\mathrm{N} 2$

$\mathrm{N} 2-\mathrm{Rh} 1-\mathrm{Cl} 2^{\mathrm{i}}$

$\mathrm{N} 1-\mathrm{Rh} 1-\mathrm{Cl} 2$

N2-Rh1-Cl2

$\mathrm{Cl} 2 \mathrm{i}-\mathrm{Rh} 1-\mathrm{Cl} 2$

N1-Rh1-Cl1

N2-Rh1-Cl1

Cl2-Rh1-Cl1

79.09(6)

158.17(12)

87.43(6)

$89.37(2)$

92.34(6)

178.74(4)

180.0

100.91(6)

90.63(2)

Torsion angles $\left[{ }^{\circ}\right]$

Rh1-N2-N3-C4

Rh1-N1-C1-C9

Rh1-N1-C1-C2

Rh1-N2-C2-C3

Rh1-N2-C2-C1

165.4(2)

$-179.48(19)$

$1.8(2)$

$-170.14(18)$

$5.6(3)$

Symmetry code: (i) $-x+1, y,-z+3 / 2$. bond angles $\mathrm{N} 1-\mathrm{Rh} 1-\mathrm{Cl} 2 / \mathrm{N} 2$ approach $90^{\circ}$, while the N2-Rh1$\mathrm{Cl} 1 / \mathrm{Cl} 2$ angles are larger than $90^{\circ}$, showing the steric influence of a bulky $\mathrm{H}_{2} \mathrm{~L}^{t \mathrm{Bu}}$ chelating ligand. The group Rh1Cl1N1N2 is perfectly planar since there is no displacement from the same weighted least-squares plane. The angle between the N2C2C3C4N3 ring plane and the Rh1Cl1N1N2 plane is $9.64(7)^{\circ}$ confirming a slight distortion from the planarity of the ligand skeleton.

The crystal packing of complex $\mathbf{1} \cdot 2 \mathrm{H}_{2} \mathrm{O}$ (Fig. S1 $\dagger$ ) is based on hydrogen bonding interactions involving the water molecules, the hydrogen atom attached to the N3 nitrogen atom, and all $\mathrm{Cl}$ ligands. The water molecules, as a two-time donor to $\mathrm{Cl}$ and one time acceptor to $\mathrm{NH}$, form three hydrogen bonds (Table S1†) leading to an infinite spiral chain along the $c$ axis (Fig. $\mathrm{S} 1 \dagger) .{ }^{11}$

\section{Kinetic studies}

The substitution reactions of complex 1 with L-Met, GSH, $5^{\prime}$-GMP and L-His. Complexes of metal ions from the $9^{\text {th }}$ group of the Periodic Table are characterized by their kinetic inertness and accordingly slow substitution reactions are typical of these complexes. In the last few years, it has been shown that introduction of different spectator ligands in the coordination sphere of $\mathrm{Rh}^{\mathrm{III}}$ complexes can improve the reactivity of these complexes. ${ }^{4}$ To get an idea of the reactivity of the $\mathrm{Rh}^{\mathrm{III}}$ complex under physiological conditions, the substitution reactions of the $\mathrm{Rh}^{\text {III }}$ complex, (1), with selected nucleophiles (Fig. 1) were investigated. The change in absorbance was followed, at suitable wavelengths, as a function of time at $310 \mathrm{~K}$ and $\mathrm{pH} \approx 7.2$ in $25 \mathrm{mM}$ Hepes buffer and $50 \mathrm{mM} \mathrm{NaCl}$. 
The proposed reaction pathways for all observed substitution processes are presented in Scheme 1.

In the present study direct nucleophilic attack proceeds in a reversible manner as mentioned in Scheme 1. All kinetic experiments were performed under pseudo-first-order conditions, for which the concentration of the $\mathrm{Rh}^{\mathrm{III}}$ complex was always in at least a 10-fold excess. To suppress the solvolytic pathway, a $50 \mathrm{mM} \mathrm{NaCl}$ solution was added.

The rate constants for substitution could be determined, under pseudo-first-order conditions, from the plot of the linear dependence of $k_{\text {obsd }} v s$. the total complex concentration, according to eqn (1). All kinetic data are summarized in Tables S2-S5 (ESI $\dagger$ ).

$$
k_{\mathrm{obsd}}=k_{2}[\mathbf{1}]+k_{1}\left[\mathrm{Cl}^{-}\right]
$$

The direct nucleophilic attack is characterized by the rate constant $k_{2}$, and the reverse reactions are presented by the rate constant $k_{1}$. The second-order rate constant $k_{2}$, characterizing the formation of the product, can be evaluated from the slope of a plot $k_{\text {obsd }} v s$. the $\mathrm{Rh}^{\mathrm{III}}$ complex concentration. The experimental results for the displacement of a chloride ion from complex 1 are summarized in Table 2. Representative plots are shown in Fig. 3 (others are given in the ESI Fig. S2 $\dagger$ ).

According to the values of $k_{2}$, summarized in Table 2, the used nucleophiles are good entering ligands for the substitution reactions of the $\mathrm{Rh}^{\mathrm{III}}$ complex. Comparing the reactivity of the nucleophiles we observed that the reactivity decreases in the following order: $5^{\prime}$-GMP $>$ GSH $>$ L-Met $>_{\text {L-His }}$ at $310 \mathrm{~K}$. To date, there are not many studies of substitution reactions of

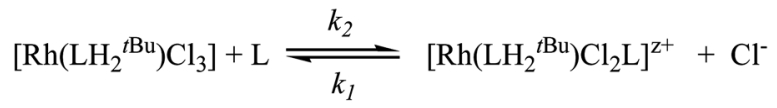

$$
\begin{aligned}
& \text { L= L-Met, GSH, 5'-GMP, L-His }
\end{aligned}
$$

Scheme 1 Schematic representation of the substitution reactions of the 1 complex with the nucleophiles: L-Met, GSH, 5'-GMP and L-His.

Table 2 The rate constants for the substitution reactions of the $\mathrm{Rh}^{\text {III }}$ complex with L-Met, GSH, 5'-GMP, and L-His at pH $=7.2(25 \mathrm{mM}$ Hepes

\begin{tabular}{|c|c|c|c|c|c|}
\hline & \multirow[b]{2}{*}{$T(\mathrm{~K})$} & \multicolumn{4}{|c|}{$\left[\mathrm{Rh}^{\mathrm{III}}\left(\mathrm{H}_{2} \mathrm{~L}^{t \mathrm{Bu}^{\prime}}\right) \mathrm{Cl}_{3}\right]$} \\
\hline & & $\begin{array}{l}10^{1} k_{2} \\
\left(\mathrm{M}^{-1} \mathrm{~s}^{-1}\right)\end{array}$ & $\begin{array}{l}10^{4} k_{1}\left[\mathrm{Cl}^{-}\right] \\
\left(\mathrm{M}^{-1} \mathrm{~s}^{-1}\right)\end{array}$ & $\begin{array}{l}\Delta H_{2}{ }^{\neq} \\
\left(\mathrm{kJ} \mathrm{mol}^{-1}\right)\end{array}$ & $\begin{array}{l}\Delta S_{2}^{\neq} \\
\left(\mathrm{J} \mathrm{K}^{-1} \mathrm{~mol}^{-1}\right)\end{array}$ \\
\hline \multirow[t]{3}{*}{ L-Met } & 288.0 & $1.7 \pm 0.1$ & $0.48 \pm 0.01$ & & \\
\hline & 298.0 & $1.9 \pm 0.1$ & $0.32 \pm 0.01$ & $11 \pm 2$ & $-240 \pm 5$ \\
\hline & 310.0 & $2.4 \pm 0.2$ & $0.15 \pm 0.03$ & & \\
\hline \multirow[t]{3}{*}{ 5'-GMP } & 288.0 & $1.0 \pm 0.1$ & $0.14 \pm 0.01$ & & \\
\hline & 298.0 & $2.3 \pm 0.2$ & $0.35 \pm 0.01$ & $43 \pm 5$ & $-130 \pm 20$ \\
\hline & 310.0 & $4.1 \pm 0.1$ & $0.53 \pm 0.02$ & & \\
\hline GSH & 310.0 & $2.9 \pm 0.3$ & $0.87 \pm 0.05$ & - & - \\
\hline $\mathrm{L}-\mathrm{His}$ & 310.0 & $2.2 \pm 0.2$ & $1.01 \pm 0.04$ & - & - \\
\hline
\end{tabular}
buffer) in the presence of $50 \mathrm{mM} \mathrm{NaCl}$

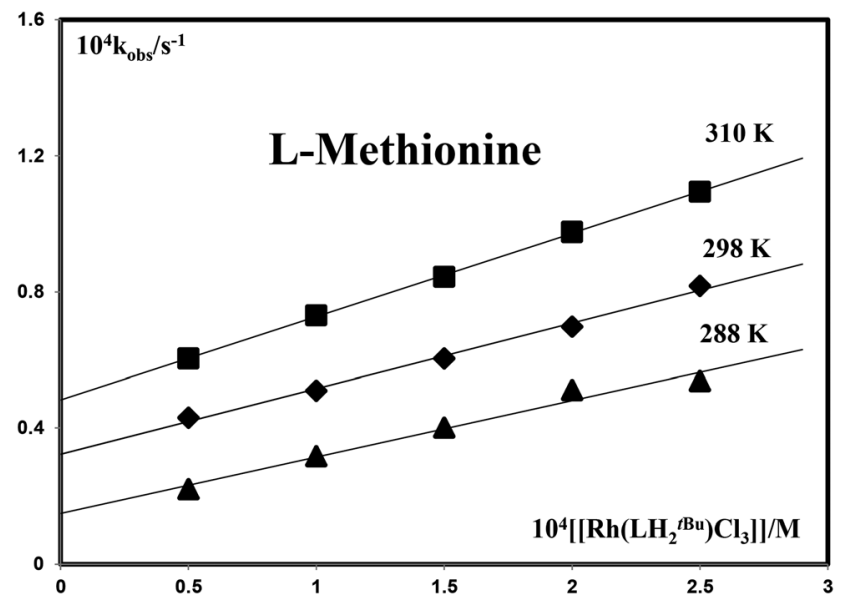

Fig. 3 Pseudo-first-order rate constants plotted as a function of complex 1 concentration for the substitution reactions of complex 1 with L-Met at $\mathrm{pH}=7.2(25 \mathrm{mM}$ Hepes buffer) in the presence of $50 \mathrm{mM}$ $\mathrm{NaCl}$.

different small biomolecules and $\mathrm{Rh}^{\mathrm{III}}$ complexes, thus the obtained results were compared with the results obtained for substitution reactions of few $\mathrm{Pt}^{\mathrm{II}}$ complexes. ${ }^{13}$ Based on the comparisons, it was observed that the order of reactivity of biomolecules in the substitution reactions with the $\mathrm{Rh}$ (III) complex was opposite to the obtained order for Pt(II) complexes (L-Met > GSH > 5'-GMP). In order to explain the fact stated, it is necessary to take a combination of various factors that attribute to the observed scenario. In this context, the other factors such as the type (group, period) ${ }^{12}$ and the oxidation state of the metal, ligands, co-ligands, (co)solvents, etc. contribute to the different affinities towards biomolecules. But in this context, further detailed theoretical investigations (in solution) are needed, which are beyond the focus of this present study.

The activation parameters $\Delta H^{\neq}$and $\Delta S^{\neq}$(Table 2) were calculated using the Eyring equation for the reactions with L-Met and 5'-GMP. The activation parameters support an associative mechanism for each of these reactions, which are supported by the significantly negative activation entropies.

The substitution reactions of $\left[\mathrm{Rh}^{\mathrm{III}}\left(\mathrm{H}_{2} \mathrm{~L}^{t \mathrm{Bu}}\right) \mathrm{Cl}_{3}\right]$ with a series of duplex DNAs and RNA. The interaction of DNA and cisplatin is one of the best-explained interactions of DNA molecules and metal ions. Cisplatin anticancer activity is today known to involve disruption of repair and induction of apoptosis as a consequence of covalent modification of nuclear DNA. ${ }^{1-3,14}$ However, the new generation of transition metal complexes, such as $\mathrm{Rh}^{\mathrm{III}}$ complexes, do not have DNA as a favored target site. Of note is that both proteins and RNA have been experimentally verified as targets of the new generation of metallodrugs. $^{2-4}$ In an attempt to prove that DNA is a possible target of rhodium(III) complexes, we have studied the kinetics of reactions of complex 1 with a duplex of DNA-1, DNA-2, and DNA-3 (Scheme 2). Also, the reaction with one of the duplex RNAs was studied for comparison. 

DNA-1
(a) 5'-CTT CTT GGT TCT CTT-3'
(b) 3'-GAA GAA CCA AGA GAA-5'
DNA-2
(a) 5'-TCT CCT TCT TGG TTC TCT TCT C-3'
DNA-3
(b) 3'-A GAG AGG AAG AAC CAA GAG AAG-5'
(a) 5'-TCT СCT TCT TGT GTC TCT TCT C-3'
(b) 3'-A GAG AGG AAG AAC ACA GAG AAG-5'
RNA-1
(a) 5'-UUC UUG GUU CUC U-3'

Scheme 2 Schematic representation of the used duplex of DNA or RNA.

All reactions were studied by the conventional UV-Vis methodology. Investigation of how the overall length and changes of base pairing in the close vicinity of a centrally located GGsite affect the rate of $\mathrm{Rh}^{\mathrm{III}}$ binding was performed. For this purpose, the reactivity of three different DNA-1, DNA-2, and DNA-3 duplex DNAs was monitored at $310 \mathrm{~K}$. In addition, the reaction between the $\mathrm{Rh}^{\mathrm{III}}$ complex and 13-mer duplex RNA was also monitored at $310 \mathrm{~K}$.

Metal-induced kinetics were studied after the addition of the rhodium(III) complex 1 to the buffered and temperature equilibrated solutions of duplex DNAs or RNA. Pseudo-first order conditions were applied, at least a 10-fold excess of the $\mathrm{Rh}^{\mathrm{III}}$ complex, compared with the total DNA or RNA-strand concentration $\left(C_{\mathrm{T}}\right)$, was used to allow for quantitative determination of observed reaction rate constants $\left(k_{\text {obsd }}\right)$ by a fit of a single-exponential function to the experimentally obtained
$\Delta A$-values $\left(\Delta A_{t}=A_{t}-A_{t=0}\right)$. The standard expression for the exponential decay according to eqn (2) was used for determination of $k_{\text {obsd }}$, with $\Delta A_{\infty}$ denoting the maximum absorbance difference reached at the end of the studied time interval.

$$
\Delta A_{t}=\Delta A_{\infty}\left(1-\exp \left(-k_{\mathrm{obsd}} t\right)\right)
$$

The obtained representative kinetic traces, together with the corresponding fitted single-exponential functions, are shown in Fig. S3. $\dagger$

The observed rate constants were plotted as a function of added concentration of complex $\mathbf{1}$; a linear dependence on $\mathrm{C}_{(\mathbf{1})}$ (Fig. 4). The obtained linear dependence is in agreement with a reaction mechanism in which the interaction between complex 1 and duplex DNA or duplex RNA constitutes the rate determin-

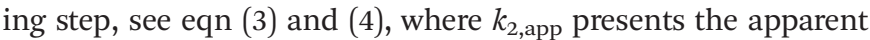
second-order rate constant for the studied reaction. For such a reaction model, the second-order rate constant $k_{2 \text {,app }}$ can thus be directly obtained from the slope of a plot of $k_{\text {obsd }} v s . \mathrm{C}_{(\mathbf{1})} \cdot{ }^{15,16}$

$$
\begin{gathered}
\operatorname{dsDNA}(\text { or dsRNA })+(\mathbf{1}) \stackrel{k_{2, \text { app }}}{\rightleftharpoons} \operatorname{dsDNA}(\text { or dsRNA })-\mathbf{1}+\mathrm{Cl}^{-} \\
k_{\text {obsd }}=k_{2, \text { app }}[\mathbf{1}]+k_{-2}\left[\mathrm{Cl}^{-}\right]
\end{gathered}
$$

The obtained rate constants for the reaction between $\mathrm{Rh}^{\mathrm{III}}$ complex 1 and the chosen DNA or RNA duplex are summarized in Table 3. Representative plots are shown in Fig. 4 .
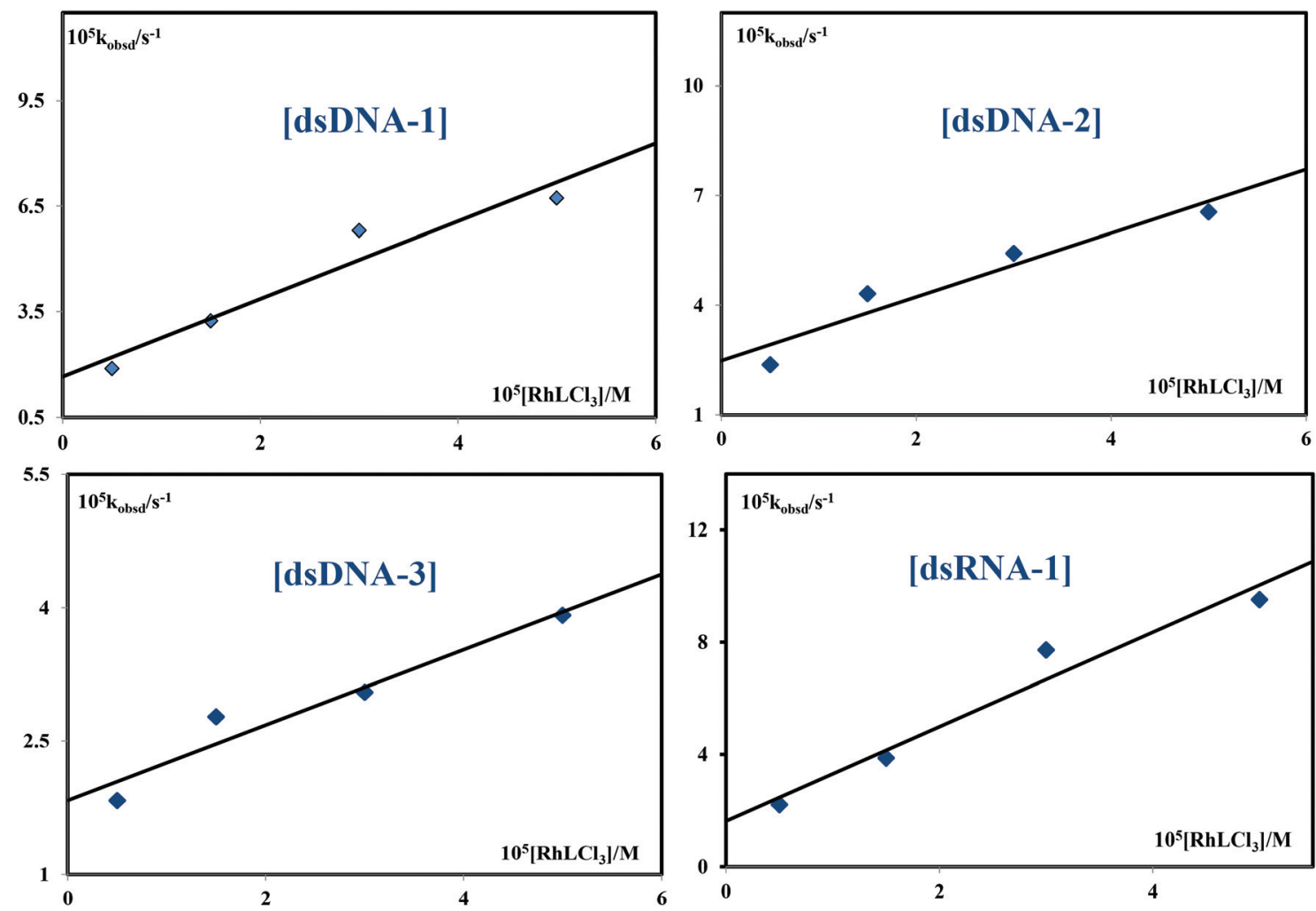

Fig. 4 Pseudo-first-order rate constants plotted as a function of complex 1 concentration for the substitution reactions of the complexes 1 with DNA-1, DNA-2, DNA-3, and RNA-1 in PBS buffer solution at $\mathrm{pH}=7.4, T=310 \mathrm{~K}$. 
Table 3 The obtained rate constants, $k_{2, a p p}$, for the reaction between complex 1 and duplex DNAs and RNA in PBS buffer at $310 \mathrm{~K}$

\begin{tabular}{lll}
\hline & $k_{2, \text { app }}\left(\mathrm{M}^{-1} \mathrm{~s}^{-1}\right)$ & $k_{-2}\left[\mathrm{Cl}^{-}\right]\left(10^{5} \mathrm{M}^{-1} \mathrm{~s}^{-1}\right)$ \\
\hline DNA-1 & $1.11 \pm 0.02$ & $2.0 \pm 0.2$ \\
DNA-2 & $0.87 \pm 0.01$ & $2.5 \pm 0.1$ \\
DNA-3 & $0.42 \pm 0.01$ & $1.8 \pm 0.1$ \\
RNA-1 & $1.68 \pm 0.01$ & $1.6 \pm 0.1$
\end{tabular}

From the obtained and above presented data it can be seen that the investigated complex 1 interacts with duplex DNAs as well as with RNA. Various length duplexes of DNA, 15GG (DNA-1), and 22GG (DNA-2) were used in this study. The following order of reactivity was obtained: RNA-1 > DNA-1 > DNA-2 > DNA-3. It turned out that the shorter 15GG duplex reacts faster than the longer $22 \mathrm{GG}$ duplex, which is consistent with previously published results. ${ }^{15,16}$ Furthermore, the duplexes of the same length, but of different sequences, 22GG (DNA-2) and 22GTG (DNA-3) were studied. It was observed that a higher reactivity is achieved with a DNA duplex with a centrally located GG-sequence than with a 22GTG duplex in which the GG-sequence is separated by a $\mathrm{T}$ base. In all studied reactions similar intercepts could be evaluated, Fig. 4 and eqn (4).

\section{DNA interactions}

UV-Vis absorption studies. UV-Vis CT-DNA titrations were carried out using complex 1. The intrinsic equilibrium binding constant $\left(K_{\mathrm{b}}\right)$ was evaluated. Therefore, the metal complex absorption titration studies were carried out at room temperature using a fixed concentration of complex 1 $(12.5 \mu \mathrm{M})$ in PBS buffer, and varying the amount of CT-DNA $(0-20 \mu \mathrm{M}) .{ }^{17} \mathrm{~A}$ studied systematic addition of CT-DNA to a solution of the $\mathrm{Rh}^{\mathrm{III}}$ complex resulted in a significant hyperchromic effect with the appearance of a new band at $258 \mathrm{~nm}$, but with only insignificant absorption changes in the 300-500 nm region, see Fig. 5. A significant hyperchromic shift with the appearance of a new signal in UV-Vis spectra clearly suggested a strong interaction between the complex and CT-DNA through external contacts, presumably hydrogen bonding and electrostatic interactions. ${ }^{18}$

\section{Ethidium bromide (EthBr) displacement studies}

Interaction of complex 1 with CT-DNA has also been performed by EthBr displacement studies, which provide strong evidence about competitive binding of drugs with CT-DNA. EthBr itself fluorescences weakly, ${ }^{18}$ however in the presence of CT-DNA it strongly emits at $\sim 600 \mathrm{~nm}$ due to strong intercalation between EthBr and DNA base pairs. Interaction of complex 1 with CT-DNA led to significant quenching of fluorescence intensity due to the displacement of EthBr from the EthBr-DNA complex. ${ }^{19}$ The quenching parameters for the $\mathrm{Rh}^{\mathrm{III}}$ complex 1 have been calculated using the Stern-Volmer equation. Therefore, $\mathrm{EthBr}$ displacement studies have been performed by changing the concentration of metal complexes and monitoring the emission intensity of the EthBr-DNA complex. ${ }^{17}$ An increase in the concentration of $1(0-30 \mu \mathrm{M})$ exhibited a significant decrease in the fluorescence intensity with a noticeable red shift. It indicated that EthBr is released from the EthBr-DNA complex due to its exchange by the studied complex. Thus, complex $\mathbf{1}$ is capable of displacing EthBr from the EthBr-DNA complex and could strongly interact with DNA binding sites (Fig. 6). ${ }^{20}$

As indicated above, the fluorescence intensity at $612 \mathrm{~nm}$ was used to estimate $K_{\mathrm{sv}}$ but the fluorescence quenching data

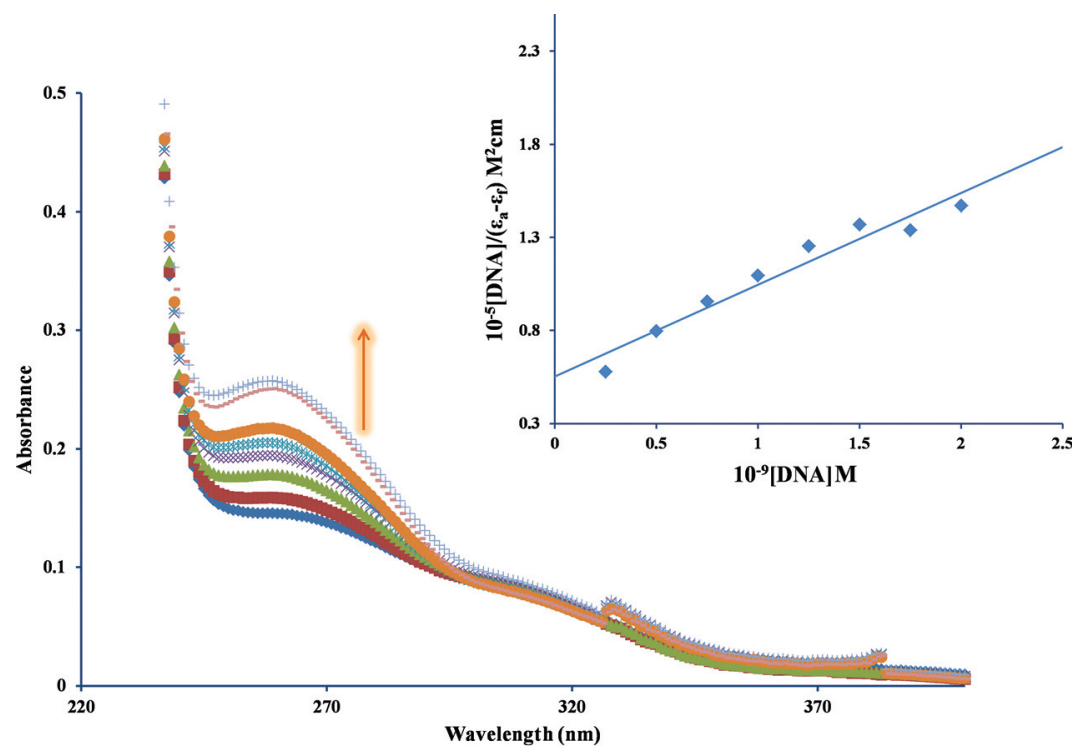

Fig. 5 UV-Vis titration spectra of complex $1(12.5 \mu \mathrm{M})$ in PBS buffer (phosphate buffer solution $=0.01 \mathrm{M}, C_{\mathrm{NaCl}}=0.137, C_{\mathrm{KCl}}=0.0027 \mathrm{M}, \mathrm{pH} 7.4$ ) with the increasing concentration of CT-DNA $(0-20 \mu \mathrm{M})$. The arrow shows hyperchromism in the spectral band. Insert graph: plots of [DNA]/( $\left.\varepsilon_{\mathrm{A}}-\varepsilon_{f}\right)$ vs. [DNA]. 


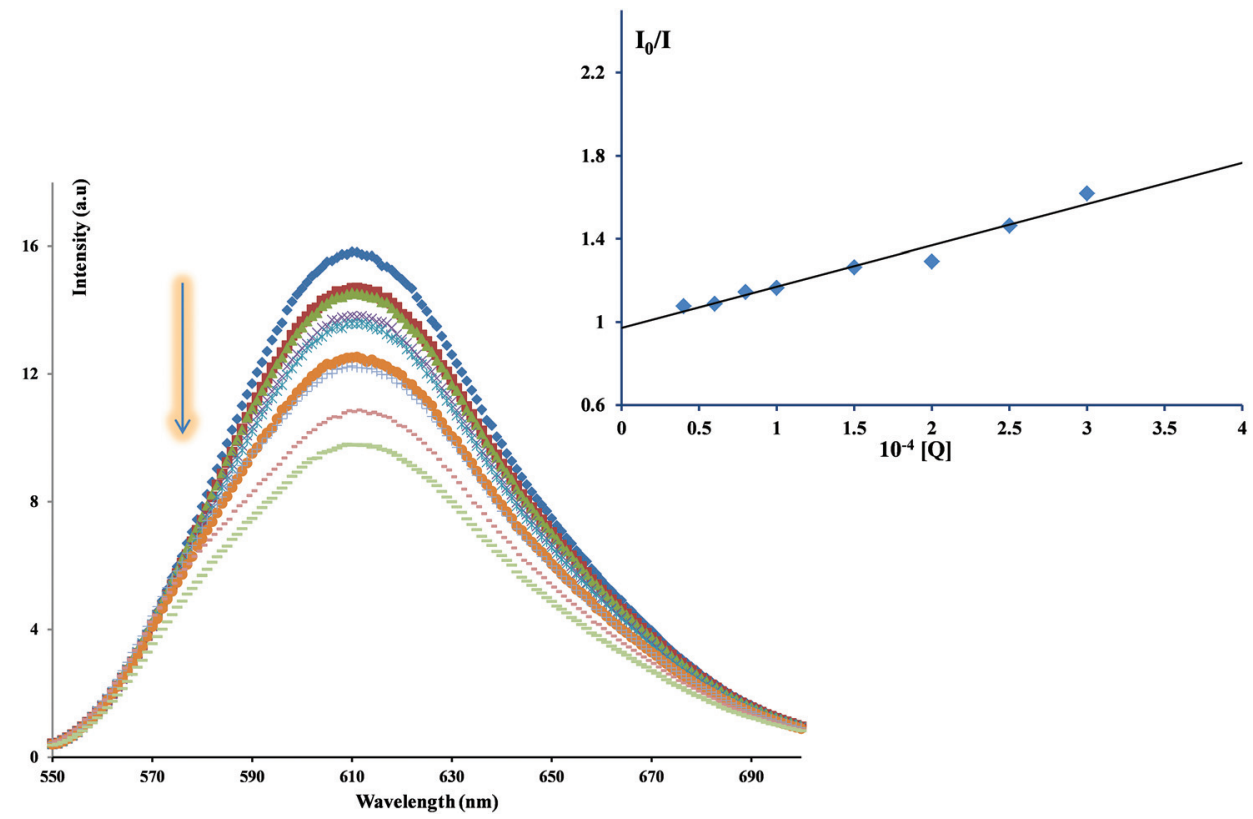

Fig. 6 Fluorescence titration spectra of EthBr-DNA and of $\operatorname{EthBr}(10 \mu \mathrm{M})$ bound to DNA $(10 \mu \mathrm{M})$ in the presence of varying amounts of complexes 1. [The arrow shows changes in the fluorescence intensity upon increasing concentration of $1(4-30 \mu M)$.] Insert graph: Stern-Volmer plots for EthBr-DNA fluorescence titration with 1.

Table 4 The obtained constants for the interaction between complex 1 and CT-DNA

\begin{tabular}{llll}
\hline & {$\left[\mathrm{Rh}^{\mathrm{III}}\left(\mathrm{H}_{2} \mathrm{~L}^{t \mathrm{Bu}}\right) \mathrm{Cl}_{3}\right]$} & & \\
\cline { 2 - 4 } & $K_{\mathrm{b}}\left[\mathrm{M}^{-1}\right]$ & $K_{\mathrm{sv}}\left[\mathrm{M}^{-1}\right]$ & $K_{\mathrm{bin}}\left[\mathrm{M}^{-1}\right]$ \\
\hline CT-DNA & $(9.7 \pm 0.1) \times 10^{4}$ & $(1.9 \pm 0.1) \times 10^{4}$ & $(2.4 \pm 0.1) \times 10^{4}$ \\
BSA & - & $(3.0 \pm 0.1) \times 10^{4}$ & $(7.4 \pm 0.1) \times 10^{3}$
\end{tabular}

could be used to determine the binding sites $(n)$ and the equilibrium-binding constant by using the Scatchard equation:

$$
\log \left(I_{0} / I\right) / I=\log K_{\text {bin }}+n \log [\mathrm{Q}]
$$

$K_{\text {bin }}$ is the binding constant of complex 1 with CT-DNA and $n$ is the number of binding sites. The number of binding sites $(n)$ and the binding constant $\left(K_{\text {bin }}\right)$ have been calculated from

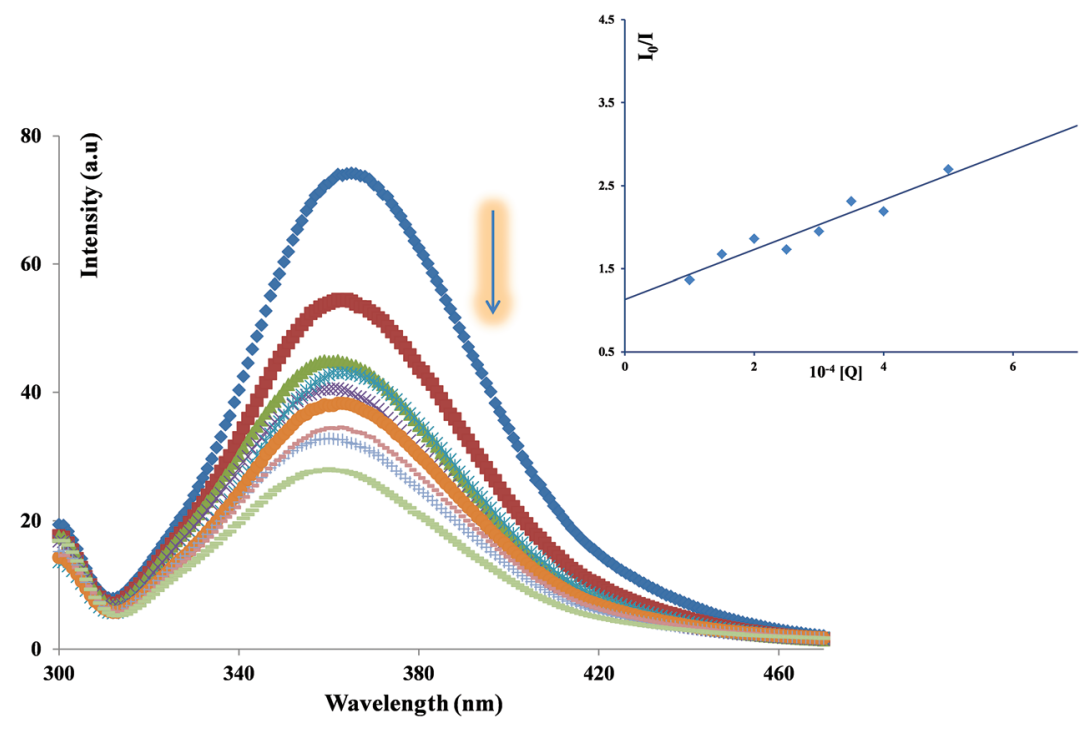

Fig. 7 Emission spectrum of BSA $\left(2 \mu \mathrm{M} ; \lambda_{\mathrm{ex}}, 295 \mathrm{~nm} ; \lambda_{\mathrm{em}} 363 \mathrm{~nm}\right)$ in the presence of increasing amounts of $1(0-60 \mu \mathrm{M})$. The arrow shows that the emission intensity changes upon increasing the concentration of the complex. Insert graph: plots of $I_{0} / / \mathrm{vs}$. [Q]. 
the plot of $\log \left(I_{0} / I\right) / I$ vs. $\log [\mathrm{Q}]$ (see Fig. $\mathrm{S} 4 \dagger$ ). The calculated value of the number of binding sites $(n)$ is 1.03 . The value of $(n)$ is approximately equal to 1 , and it indicates the existence of one binding site in DNA for the rhodium(III) complex 1.

According to the values of constants presented in Table 4 a good interaction of the studied complex with CT-DNA is evident. Also, the results obtained by fluorescence spectroscopy are in excellent agreement with the UV-Vis spectral data, demonstrating that the studied complex interacts with CT-DNA.

\section{Protein binding studies}

To gain a better insight into the interaction between the studied complex $\mathbf{1}$ and BSA, BSA fluorescence quenching experiments in the presence of the $\mathrm{Rh}^{\mathrm{III}}$ complex $\mathbf{1}$ were performed. Fluorescence spectroscopy can provide useful information about the structure, dynamics, and protein folding. ${ }^{21-23}$ Changes in the fluorescence spectrum of BSA upon addition of different concentrations of complex 1 $(0-60 \mu \mathrm{M})$ in the range of $300-500 \mathrm{~nm}\left(\lambda_{\mathrm{ex}}=295 \mathrm{~nm}\right)$ are presented in Fig. 7. As illustrated here, a decrease in the fluorescence intensity at $363 \mathrm{~nm}$ and some interactions between the complexes and BSA protein are observed. Fluorescence quenching data have been analyzed using the Stern-Volmer equation and the quenching constant $\left(K_{\mathrm{sv}}\right)$ was calculated by using the plot of $I_{0} / I$ vs. [Q], Fig. 7. The equilibrium binding constant $K_{\text {bin }}$ and $n$, the number of binding sites, can be analyzed by the Scatchard equation (see Fig. S5, ESI $\dagger$ ). The value of $n$ for the studied complex is 0.85 which is approximate to 1 and strongly suggests the existence of a single binding site in BSA for the $\mathrm{Rh}^{\mathrm{III}}$ complex 1 .

According to the obtained constants, complex 1 interacts satisfactorily with BSA protein (Table 4). By comparing the obtained quenching constant $\left(K_{\mathrm{sv}}\right)$ for the interaction of the rhodium(III) complex with CT-DNA and BSA it can be seen that they are almost similar (Table 4).

\section{Conclusion}

In this study, a novel rhodium(III) complex $\left[\mathrm{Rh}^{\mathrm{III}}\left(\mathrm{H}_{2} \mathrm{~L}^{t \mathrm{Bu}}\right) \mathrm{Cl}_{3}\right]$ (1) with pincer-type tridentate nitrogen donor ligands and three vacant coordination sites was synthesized. X-ray structure analysis on single crystals of complex $\mathbf{1} \cdot 2 \mathrm{H}_{2} \mathrm{O}$ was carried out, indicating that the rhodium center in complex $\mathbf{1}$ is coordinated in a slightly distorted octahedral geometry with the tridentate N,N,N-donor adopting a mer arrangement and an essentially planar ligand skeleton. Kinetic experiments were performed with selected small bio-molecules (i.e. L-methionine, L-histidine, glutathione, and guanosine-5'monophosphate) under pseudo-first-order conditions as a function of complex concentration and temperature using UV-Vis spectrophotometry. These measurements showed that the synthesized complex has good affinity toward studied ligands and the obtained order of reactivity is: $5^{\prime}$-GMP > GSH > L-Met > L-His with small differences in the values of obtained second-order rate constants. Thus, this implies that rhodium(III) ions have almost the same affinity to bound to sulfur-donor biomolecules and nitrogen-donor biomolecules, which is in accordance with the fact that $\mathrm{Rh}^{\mathrm{III}}$ belongs to the borderline group, i.e. this metal ion is soft-hard acid. Also the kinetic measurements between complex 1 and a duplex DNA and RNA were performed. These results show a higher reactivity of the $\mathrm{Rh}^{\mathrm{III}}$ complex toward a duplex RNA than DNA, and with the shorter 15mer DNA reacting faster compared with the $22 \mathrm{mer}$ DNA. Furthermore, it was observed that a better reactivity is achieved with a DNA duplex with a centrally located GGsequence than with a 22 GTG duplex in which the GG-sequence is separated by a $\mathrm{T}$ base. The interaction between complex 1 and calf thymus DNA (CT-DNA) and bovine serum albumin (BSA) was also examined by absorption (UV-Vis) and emission spectral studies (EthBr displacement studies). Overall, this examination shows that the $\mathrm{Rh}^{\mathrm{III}}$ complex 1 has almost the same affinity to interact with calf thymus DNA (CT-DNA) and bovine serum albumin (BSA).

All the obtained results in this study indicate that the introduction of a pincer-type spectator ligand can improve the reactivity of rhodium(III) complexes. Furthermore, the kinetic measurements reveal a similar affinity of the complex 1 toward sulfur-donor and nitrogen-donor biomolecules, combined with good affinity toward both duplex DNA and RNA. Lastly, the $\mathrm{Rh}^{\mathrm{III}}$ complex was found to interact with both CT-DNA and BSA. Together, these observations show the reactivity characteristics needed for a potential anti-tumor agent, with the ability to target both DNA and proteins. Every new contribution in this field is highly warranted due to the current lack of clinically used metallo-based alternatives to cisplatin.

\section{Experimental}

\section{Material and methods}

L-Methionine (L-Met), glutathione (GSH), guanosine5'-monophosphate sodium salt (5'-GMP), L-histidine (L-His), and $\mathrm{RhCl}_{3} \cdot x \mathrm{H}_{2} \mathrm{O}$ were obtained from Acros Organics or Sigma Aldrich and used without further purification. Hepes buffer ( $N$-2-hydroxyethylpiperazine- $N^{\prime}$-2-ethanesulfonic acid) was obtained from Sigma Aldrich. All oligonucleotides (5'-CTT CTT GGT TCT CTT-3' and 5'-AAG AGA ACC AAG AAG-3' (DNA-1), 5'-TCT CCT TCT TGG TTC TCT TCT C-3' and 5'-GAA GAG AAC CAA GAA GGA GAG A-3' (DNA-2), 5'-TCT CCT TCT TGT GTC TCT TCT C-3' and 5'-GAA GAG ACA CAA GAA GGA GAG A-3' (DNA-3), 5'-UUC UUG GUU CUC U-3' and 5'-AGA GAA CCA AGA A-3' (RNA-1)) were purchased from IBA GmbH (IBA Nucleic Acids Synthesis, Göttingen, Germany) of HPLC grade quality. Disodium hydrogen phosphate dihydrate $\left(\mathrm{Na}_{2} \mathrm{HPO}_{4} \cdot 2 \mathrm{H}_{2} \mathrm{O}\right)$, sodium chloride $(\mathrm{NaCl})$, and potassium chloride $(\mathrm{KCl})$ were obtained from Merck. Potassium dihydrogen phosphate monohydrate $\left(\mathrm{KH}_{2} \mathrm{PO}_{4} \cdot \mathrm{H}_{2} \mathrm{O}\right)$ was obtained from Sigma. Phosphate buffers were prepared according to the literature procedure. ${ }^{24}$ The serum protein albumin and CT-DNA were used as received without further purification and the solutions were prepared with deionized water. All water used 
was of Millipore quality and autoclaved before use. All the other chemicals were of the highest purity commercially available and were used without further purification. Ultra-pure water was used in all experiments. Nucleophile stock solutions were prepared shortly before use by dissolving the chemicals. Preparation of the ligand $\mathrm{H}_{2} \mathrm{~L}^{t \mathrm{Bu}}$ was accomplished according to the literature procedures. ${ }^{25}$

\section{Synthesis and characterization of the $\mathrm{Rh}^{\mathrm{III}}$ complex $\left[\mathrm{Rh}^{\mathrm{III}}\left(\mathrm{H}_{2} \mathbf{L}^{t \mathrm{Bu}}\right) \mathrm{Cl}_{3}\right](\mathbf{1})$}

To a solution of $100 \mathrm{mg}(0.380 \mathrm{mmol}) \mathrm{RhCl}_{3} \cdot x \mathrm{H}_{2} \mathrm{O}$ in $60 \mathrm{ml}$ of ethanol was added $122.75 \mathrm{mg}(0.380 \mathrm{mmol} ; 1$ eq.) of ligand $\mathrm{H}_{2} \mathrm{~L}^{t \mathrm{Bu}}$ in $20 \mathrm{~mL}$ of ethanol. The reaction mixture was stirred overnight at $50{ }^{\circ} \mathrm{C}$ affording a yellow precipitate. The precipitate was filtered and dried in a vacuum. The product was obtained as a yellow solid, which was further purified by recrystallization from a mixture of DMF and water yielding yellow crystals (162.26 mg, 78\%). ${ }^{1} \mathrm{H}$ NMR ( $\mathrm{d}_{6}$-DMSO): $\delta=8.19$ (d, $2 \mathrm{H},{ }^{3} J_{\mathrm{HH}}=7.6 \mathrm{~Hz}$, pyridine), $7.30\left(\mathrm{t}, 1 \mathrm{H},{ }^{3} J_{\mathrm{HH}}=7.6 \mathrm{~Hz}\right.$, pyridine), 7.22 (s, 2H, pyrazole), 2.47 (s, 18H, $\mathrm{CMe}_{3}$ ) ppm. Anal. Calcd for $\left(\mathrm{C}_{19} \mathrm{H}_{25} \mathrm{Cl}_{3} \mathrm{~N}_{5} \mathrm{Rh} \cdot 1.25 \mathrm{H}_{2} \mathrm{O}\right) \mathrm{C}: 41.10 ; \mathrm{H}: 4.99 ; \mathrm{N}: 12.61$. Found: C: 40.95 ; $\mathrm{H}$ : 4.85; N: 12.96. IR (KBr, 4000-300 $\left.\mathrm{cm}^{-1}\right)$ : 3466 (N-H stretch); 2924 (C-H stretch) 1623, 1574, 1442 (C=C and $\mathrm{C}=\mathrm{N}$ stretch); 635 ( $\mathrm{Rh}-\mathrm{N}$ stretch).

The synthesized complex is poorly soluble in water, thus in all experiments an aqueous solution of complex 1 with additional $5 \%$ of DMF (v/v) was used in order to improve the solubility.

\section{Instrumentation}

NMR spectra were recorded on a $200 \mathrm{MHz}$ Varian Gemini-2000 device. Chemicals shifts $(\delta)$ are reported in ppm and referenced to tetramethylsilane. Coupling constants $(J)$ are reported in hertz $(\mathrm{Hz})$ and splitting patterns are indicated as $\mathrm{s}$ (singlet) and d (doublet). Elemental analyses (C, H, N) were performed by combustion and gas chromatographic analysis with an Elementar Vario MICRO elemental analyzer. $\mathrm{pH}$ measurements were carried out using a Mettler Delta 350 digital pH meter with a resolution $\pm 0.01 \mathrm{mV}$, with a combination glass electrode. This electrode was calibrated using standard buffer solutions of $\mathrm{pH} 4,7$, and 9 obtained from Sigma. Kinetic measurements of the rhodium(III) complex 1 were carried out on a Perkin-Elmer Lambda 25 or 35 double-beam spectrophotometer in thermostated $1.00 \mathrm{~cm}$ quartz Suprasil cells. The temperature was controlled to $\pm 0.1{ }^{\circ} \mathrm{C}$. Varian Cary 100 spectrophotometers equipped with a thermal control unit were also used in kinetic experiments. All kinetic measurements were performed under pseudo-first-order conditions, i.e., at least a 10 -fold excess of the complex was used. Fluorescence measurements were performed on a RF-1501 PC spectrofluorometer (Shimadzu, Japan).

\section{Kinetic measurements with small biomolecules}

The kinetics of the substitution of the coordinated chloride can be omitted spectrophotometrically by following the change in absorbance at suitable wavelengths as a function of time. The working wavelengths were determined by recording the spectra of the reaction mixture over the wavelength range of 220 to $450 \mathrm{~nm}$. All kinetic experiments were performed under pseudo-first-order conditions, for which the concentration of the $\mathrm{Rh}^{\mathrm{III}}$ complex 1 was always in at least a 10 -fold excess. The reactions were initiated by mixing $0.50 \mathrm{~mL}$ of the nucleophile complex solution with $2.50 \mathrm{~mL}$ of the thermally equilibrated complex solution in the UV-Vis cuvette, and reactions were followed for at least 8 half-lives. The observed pseudo-first-order rate constants, $k_{\text {obsd }}$, represent an average value of two to four independent kinetic runs for each experimental condition. Some of the reactions were studied at three temperatures $(288,298$, and $310 \mathrm{~K})$. The experimental data are summarized in the ESI (Tables S1-S4 $\dagger$ ). The values of the constants and other thermodynamic parameters were determined using the computer programs Microsoft Excel 2007 and OriginPro 8.

\section{Kinetic measurements with a series of duplex DNAs and RNA}

Kinetic studies were performed on a Varian Cary 100 spectrophotometer, equipped with a thermal control unit. Each duplex of DNA-1, DNA-2, DNA-3 and RNA-1 (Scheme 2) with equal concentrations of the (a) and (b) strands, was separately mixed in a buffer solution where the total strand concentration $\left(C_{\mathrm{T}} ; C_{\mathrm{T}}=C_{\mathrm{Xa}}+C_{\mathrm{Xb}}\right)$ was $3.0 \mu \mathrm{M}$ and the measurements were conducted. The complementary duplexes were first heated to $90^{\circ} \mathrm{C}$, after being hybridized by slow cooling $\left(0.5^{\circ} \mathrm{C} \mathrm{min}^{-1}\right)$ to $20^{\circ} \mathrm{C}$ and then heated to $37^{\circ} \mathrm{C}\left(0.5^{\circ} \mathrm{C} \mathrm{min}^{-1}\right)$ with the added complex 1. The absorbance change was measured at $\lambda=$ $260 \mathrm{~nm}$ after addition of $\mathbf{1}$, where the final concentrations of 1 were: $5,15,30$, and $50 \mu \mathrm{M}$ for up to $c a .19 \mathrm{~h}$.

\section{UV-Vis DNA interactions}

A stock solution of CT-DNA was prepared in PBS buffer, which gave a ratio of UV absorbances at $260 \mathrm{~nm}$ and $280 \mathrm{~nm}\left(A_{260}\right)$ $A_{280}$ ) of $c a \cdot 1.8-1.9$, indicating that the DNA was sufficiently free of protein and the concentration was determined by the UV absorbance at $260 \mathrm{~nm}\left(\varepsilon=6600 \mathrm{M}^{-1} \mathrm{~cm}^{-1}\right) .{ }^{26}$ The UV-Vis spectra were obtained on a Perkin-Elmer Lambda 35 or 25 double beam spectrophotometer, using $1.0 \mathrm{~cm}$ path-length quartz cuvettes $(3.0 \mathrm{~mL})$. Fluorescence measurements were performed on a RF-1501 PC spectrofluorometer (Shimadzu, Japan). The fluorescence spectra were recorded in the range of $550-750 \mathrm{~nm}$ upon excitation at $527 \mathrm{~nm}$ in all cases. The excitation and emission bandwidths were both $10 \mathrm{~nm}$.

\section{UV-Vis absorption studies}

In order to compare quantitatively the binding strength of the complexes, the intrinsic binding constant $K_{\mathrm{b}}$ was determined by monitoring the changes in absorption at the MLCT band with an increasing concentration of CT-DNA using the following eqn (5).

$$
[\mathrm{DNA}] /\left(\varepsilon_{\mathrm{A}}-\varepsilon_{\mathrm{f}}\right)=[\mathrm{DNA}] /\left(\varepsilon_{\mathrm{b}}-\varepsilon_{\mathrm{f}}\right)+1 /\left[K_{\mathrm{b}}\left(\varepsilon_{\mathrm{b}}-\varepsilon_{\mathrm{f}}\right)\right]
$$

$K_{\mathrm{b}}$ is given by the ratio of the slope to the $y$ intercept in plots $[\mathrm{DNA}] /\left(\varepsilon_{\mathrm{A}}-\varepsilon_{\mathrm{f}}\right) v s$. [DNA], where [DNA] is the concentration 
of DNA in base pairs, $\varepsilon_{\mathrm{A}}=A_{\text {obsd }} /\left[\right.$ complex], $\varepsilon_{\mathrm{f}}$ is the extinction coefficient for the unbound complex and $\varepsilon_{\mathrm{b}}$ is the extinction coefficient for the complex in the fully bound form.

\section{Ethidium bromide (EthBr) displacement studies}

The relative binding of complexes to CT-DNA was determined by calculating the quenching constant $\left(K_{\mathrm{sv}}\right)$ from the slopes of straight lines obtained from the Stern-Volmer equation (eqn (6)).

$$
I_{0} / I=1+K_{\mathrm{Sv}}[\mathrm{Q}]
$$

$I_{0}$ and $I$ are the emission intensities in the absence and the presence of the quencher (complex 1), respectively, $[\mathrm{Q}]$ is the total concentration of the quencher, and $K_{\mathrm{sv}}$ is the SternVolmer quenching constant which can be obtained from the slope of the plot of $I_{0} / I v s$. [Q].

\section{Protein binding studies}

Fluorescence spectroscopy is an efficient tool for proteinbinding studies, such as interaction of metal complexes with BSA. The fluorescence of the BSA arises due to the presence of fluorophores like tryptophan, tyrosine and phenylalanine. Accordingly, tryptophan fluorescence quenching experiments were carried out using bovine serum albumin (BSA 2.0 $\mu \mathrm{M}$ ) in PBS buffer. The quenching of the emission intensity of the tryptophan residue of BSA at $363 \mathrm{~nm}$ was monitored in the presence of the increasing concentration of the $\mathrm{Rh}^{\mathrm{III}}$ complex $1(10.0-60.0 \mu \mathrm{M})$ as a quencher. Fluorescence measurements were performed on a RF-1501 PC spectrofluorometer (Shimadzu, Japan). Fluorescence spectra were recorded from 300 to $500 \mathrm{~nm}$ at an excitation wavelength of $295 \mathrm{~nm}$. The excitation and emission bandwidths were both $10 \mathrm{~nm}$.

\section{X-ray diffraction studies}

A single crystal of complex $\left[\mathrm{Rh}^{\mathrm{III}}\left(\mathrm{H}_{2} \mathrm{~L}^{t \mathrm{tBu}}\right) \mathrm{Cl}_{3}\right] \cdot 2 \mathrm{H}_{2} \mathrm{O}\left(\mathbf{1} \cdot 2 \mathrm{H}_{2} \mathrm{O}\right)$ was selected and mounted on a glass fiber. Diffraction data were collected using the Oxford Diffraction Gemini S fourcircle goniometer equipped with a Sapphire CCD detector. The crystal to detector distance was $45.0 \mathrm{~mm}$ and graphite monochromated MoK $\alpha(\lambda=0.7107 \AA)$ radiation was used for the experiment at $293 \mathrm{~K}$. The collected data set consisted of 2 runs of 155 frames of intensity ( $1^{\circ}$ in $\omega$ ). The collected frames were integrated by using an orientation matrix determined from the frame scans. CrysAlisPro and CrysAlis RED software packages ${ }^{27}$ were used for data collection and data integration. Analysis of the integrated data did not reveal any decay. Final cell parameters were determined by a global refinement of 1975 reflections $\left(4.3<\theta<28.8^{\circ}\right)$. Collected data were corrected for absorption effects by multi-scan absorption correction using spherical harmonics as implemented in the SCALE3 ABSPACK $^{28}$ scaling algorithm.

Structure solution and refinement were carried out with the programs SHELXT and SHELXL-2014/6 respectively. ${ }^{29}$ ORTEP-3 for Windows ${ }^{30}$ was employed for molecular graphics and WinGx software was used to prepare material for publi-
Table 5 Crystallographic data and refinement parameters for complex $\left[\mathrm{Rh}^{\prime \prime \prime}\left(\mathrm{H}_{2} \mathrm{~L}^{\mathrm{tBu}}\right) \mathrm{Cl}_{3}\right] \cdot 2 \mathrm{H}_{2} \mathrm{O}\left(1 \cdot 2 \mathrm{H}_{2} \mathrm{O}\right)$

\begin{tabular}{ll}
\hline & $\mathbf{1 \cdot 2 \mathrm { H } _ { 2 } \mathrm { O }}$ \\
\hline Chemical formula & $\mathrm{C}_{9.50} \mathrm{H}_{14.50} \mathrm{Cl}_{1.50} \mathrm{~N}_{2.50} \mathrm{ORh}_{0.50}$ \\
$M_{\mathrm{r}}$ & 284.37 \\
Crystal system, space group & Orthorhombic, $P b c n$ \\
$a, b, c(\AA)$ & $20.7982(6), 10.8952(4), 10.9832(4)$ \\
$V\left(\AA^{3}\right)$ & $2488.80(15)$ \\
$Z$ & 8 \\
$F(000)$ & 1160 \\
$\mu\left(\mathrm{mm}^{-1}\right)$ & 1.03 \\
Crystal shape & Prism \\
Colour & Yellow \\
Crystal size $($ mm $)$ & $0.46 \times 0.18 \times 0.15$ \\
Absorption correction & Multi-scan CrysAlis PRO, Agilent \\
& Technologies, empirical absorption \\
& correction using spherical harmonics, \\
& implemented in SCALE3 ABSPACK \\
$T_{\text {min }}, T_{\text {max }}$ & scaling algorithm. \\
No. of measured, & $0.978,1.000$ \\
independent and observed & $7072,2867,2220$ \\
{$[I>2 \sigma(I)]$ reflections } & \\
$R_{\text {int }}$ & \\
$\theta$ values $\left({ }^{\circ}\right)$ & 0.020 \\
Range of $h, k, l$ & $\theta_{\text {max }}=29.1, \theta_{\text {min }}=3.3$ \\
$R\left[F^{2}>2 \sigma\left(F^{2}\right)\right]$, w $R\left(F^{2}\right), S$ & $h=-15 \rightarrow 26, k=-7 \rightarrow 14, l=-14 \rightarrow 12$ \\
No. of reflections & $0.033,0.073,1.10$ \\
No. of parameters & 2867 \\
No. of restraints & 161 \\
H-atom treatment & 2 \\
& $\mathrm{H}$ atoms treated by a mixture of \\
$\rho_{\text {max }}, \rho_{\text {min }}\left(\mathrm{e} \AA^{-3}\right)$ & independent and constrained \\
& refinement \\
& $0.31,-0.45$ \\
&
\end{tabular}

Computer programs: CrysAlis PRO, Agilent Technologies, Version 1.171.37.35 (release 13-08-2014 CrysAlis171 .NET) (compiled August 13, 2014, 18:06:01), SHELXL2014/6 (Sheldrick, 2014).

cation. ${ }^{31}$ Full-matrix least-squares refinement was carried out by minimizing $\left(F_{\mathrm{o}}{ }^{2}-F_{\mathrm{c}}{ }^{2}\right)$. All non-hydrogen atoms were refined anisotropically and refinement was carried out without geometric or ADP restraints. Hydrogen atoms attached to carbon atoms in methyl groups were placed in geometrically idealized positions and refined as riding on their parent atoms with $U_{\text {iso }}(\mathrm{H})=1.5 U_{\text {eq }}(\mathrm{C})$. The positions of all other hydrogens were found from the inspection of the difference Fourier maps. Crystal data and experimental details of the structure determination are listed in Table 5. Crystallographic data have been deposited with the Cambridge Crystallographic Data Centre as supplementary publications no. CCDC 1482787.

\section{Acknowledgements}

The authors gratefully acknowledge financial support from the Ministry of Science and Technological Development of the Republic of Serbia, project No. 172011 and the Swedish Cancer foundation (Grant to S.K.C.E No. 13 0317). M. M. would like to thank Prof. Dr. Sofi K. C. Elmroth for hosting this work and continuously support at Kemicentrum, Lund University, Sweden and Dr Alak Alchikh for her support. 


\section{Notes and references}

1 Bioinorganic Medicinal Chemistry, ed. E. Alessio, Wiley-VCH, Weinheim, 2011, ch. 1-4.

2 (a) P. E. N. Barry and J. P. Sadler, Chem. Commun., 2013, 49, 5106; (b) L. Ronconi and J. P. Sadler, Coord. Chem. Rev., 2007, 251, 1633.

3 S. Dilruba and G. V. Kalayda, Cancer Chemother. Pharmacol., 2016, 77, 1103.

4 C.-H. Leung, H.-J. Zhong, D. S.-H. Chan and D.-L. Ma, Coord. Chem. Rev., 2013, 257, 1764; Y. Geldmacher, M. Oleszak and W. S. Sheldrick, Inorg. Chim. Acta, 2012, 393, 84.

5 Z. Liu, I. Romero-Canelón, B. Qamar, J. M. Hearn, A. Habtemariam, N. P. E. Barry, A. M. Pizarro, G. J. Clarkson and P. J. Sadler, Angew. Chem., Int. Ed., 2014, 53, 3941.

6 S. H. van Rijt, I. Romero-Canelón, Y. Fu, S. D. Shnyder and P. J. Sadler, Metallomics, 2014, 6, 1014.

7 N. Cutillas, G. S. Yellol, C. Haro, C. Vicente, V. Rodriguez and J. Ruil, Coord. Chem. Rev., 2013, 257, 2784.

8 J. L. Bear, R. A. Howard and J. E. Korn, Inorg. Chim. Acta, 1979, 32, 123.

9 (a) D. Morales-Morales and C. M. Jensen, The Chemistry of Pincer Compounds, Elsevier, Amsterdam, 2007; (b) J. T. Singleton, Tetrahedron, 2003, 59, 1837; (c) L. C. Liang, Coord. Chem. Rev., 2006, 250, 1152; (d) V. C. Gibson, C. Redshaw and G. A. Solan, Chem. Rev., 2007, 107, 1745; (e) D. Pugh and A. A. Danopoulos, Coord. Chem. Rev., 2007, 251, 610; $(f)$ D. Benito-Garagorri and K. Kirchner, Acc. Chem. Res., 2008, 41, 201; $(g)$ W. Leis, H. A. Mayer and W. C. Kaska, Coord. Chem. Rev., 2008, 252, 1787; (h) M. T. Whited and R. H. Grubbs, Acc. Chem. Res., 2009, 42, 1607; ( $i$ ) J. I. van der Vlugt and J. N. H. Reek, Angew. Chem., 2009, 121, 8990, (Angew. Chem., Int. Ed., 2009, 48, 8832); ( $j$ ) H. Nishiyama and J. Ito, Chem. Commun., 2010, 46, 203; (k) J. Choi, A. H. R. MacArthur, M. Brookhart and A. S. Goldman, Chem. Rev., 2011, 111, 1761; (l) N. Selander and K. J. Szab, Chem. Rev., 2011, 111, 2048; (m) J. L. Niu, X. Q. Hao, J. F. Gong and M. P. Song, Dalton Trans., 2011, 40, 5135; (n) H. Zhang and A. Lei, Dalton Trans., 2011, 40, 8745; (o) J. I. van der Vlugt, Eur. J. Inorg. Chem., 2012, 363.

10 (a) J. A. G. Williams, Chem. Soc. Rev., 2009, 38, 1783;

(b) Y. Chi and P. T. Chou, Chem. Soc. Rev., 2010, 39, 638.

11 C. F. Macrae, P. R. Edgington, P. McCabe, E. Pidcock, G. P. Shields, R. Taylor, M. Towler and J. van de Streek, J. Appl. Crystallogr., 2006, 39, 453.
12 Z. E. Housecroft and A. G. Sharp, Inorganic Chemistry, Essex, England, 2005, ch. 6, p. 188.

13 Ž. D. Bugarčić, J. Bogojeski, B. Petrović, S. Hochreuther and R. van Eldik, Dalton Trans., 2012, 41, 12329.

14 Cisplatin, Chemistry and Biochemistry of Leading Antitumor Drugs, ed. B. Lippert, Wiley-VCH, Zürich, 1999.

15 C. Polonyi and S. K. C. Elmroth, Dalton Trans., 2013, 42, 14959.

16 C. Polonyi, A. Alshiekh, L. A. Sarsam, M. Clausén and S. K. C. Elmroth, Dalton Trans., 2014, 43, 11941.

17 (a) E. C. Long and J. K. Barton, Acc. Chem. Res., 1990, 23, 271; (b) R. F. Pasternack, E. J. Gibbs and J. Villafranca, J. Biochem., 1983, 22, 251.

18 (a) E. S. Koumousi, M. Zampakou, C. P. Raptopoulou, V. Psycharis, C. M. Beavers, S. J. Teat, G. Psomas and T. C. Stamatatos, Inorg. Chem., 2012, 51, 7699; (b) M. A. Rizvi, M. Zaki, M. Afzal, M. Mane, M. Kumar, B. A. Shah, S. Srivastav, S. Srikrishna, G. M. Peerzada and S. Tabassum, Eur. J. Med. Chem., 2015, 90, 876.

19 R. F. Pasternack, E. J. Gibbs and J. Villafranca, Biochemistry, 1983, 22, 2406.

20 (a) F. J. Meyer-Almes and D. Porschke, Biochemistry, 1993, 32, 4246; (b) Z. C. Liu, B. D. Wang, Z. Y. Yang, Y. Li, D. D. Qin and T. R. Li, Eur. J. Med. Chem., 2009, 44, 4477; (c) G. M. Howe, K. C. Wu and W. R. Bauer, Biochemistry, 1976, 19, 339.

21 E. Ramachandran, S. P. Thomas, P. Poornima, P. Kalaivani, R. Prabhakaran, V. V. Padma and K. Natarajan, Eur. J. Med. Chem., 2012, 50, 405.

22 R. P. Paitandi, R. K. Gupta, R. S. Singh, G. Sharma, B. Koch and D. S. Pandey, Eur. J. Med. Chem., 2014, 84, 17.

23 J. N. Miller, Proc. Anal. Div. Chem. Soc., 1979, 16, 203.

24 D. D. Moore, Curr. Protoc. Mol. Biol., 2001, 35, A.2.1.

25 (a) R. W. Saalfrank, A. Scheurer, R. Puchta, F. Hampel, H. Maid and F. W. Heinemann, Angew. Chem., Int. Ed., 2007, 46, 265; (b) S. Begel, A. Scheurer and R. Puchta, J. Coord. Chem., 2015, 68, 3374; (c) J. Korzekwa, A. Scheurer, F. W. Heinemann and K. Meyer, unpublished results.

26 K. A. Meadows, F. Liu, J. Sou, B. P. Hudson and D. R. McMillin, Inorg. Chem., 1993, 32, 2919.

27 Oxford Diffraction, CrysAlis CCD and CrysAlis Red, Oxford Diffraction, Abingdon, 2009.

28 SCALE3 ABSPACK CrysAlisPro, Agilent Technologies, Version 1.171.35.19.

29 G. M. Sheldrick, Acta Crystallogr., Sect. A: Fundam. Crystallogr, 2015, 71, 3.

30 L. J. Farrugia, J. Appl. Crystallogr., 1997, 30, 565.

31 L. J. Farrugia, J. Appl. Crystallogr., 1999, 32, 837. 